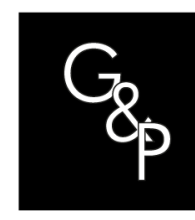

\title{
Management for maintenance of public education
}

\author{
Gestão para manutenção de edificações de ensino
}

\author{
Franciele Maria Costa Ferreira ${ }^{1}$ (D), Henor Artur de Souza ${ }^{2}$ (D) \\ ${ }^{1}$ Instituto Federal de Educação, Ciência e Tecnologia de Minas Gerais - IFMG, Departamento de Edificações, \\ Congonhas, MG, Brasil. E-mail: franciele.ferreira@ifmg.edu.br \\ ${ }^{2}$ Universidade Federal de Ouro Preto - UFOP, Departamento de Engenharia Mecânica, Programa de Pós- \\ graduação em Engenharia Civil -PROPEC, Ouro Preto, MG, Brasil. E-mail: henorster@gmail.com
}

How to cite: Ferreira, F. M. C., \& Souza, H. A. (2021). Management for maintenance of public education. Gestão \& Produção, 28(1), e4894. https://doi.org/10.1590/1806-9649.2020v28e4894

\begin{abstract}
Public education buildings require a plan for the conservation and maintenance of its various systems and facilities. In practice, it can be seen that there are major challenges in managing the maintenance of the Federal Universities in Minas Gerais State involving a lack of financial resources, disqualified and insufficient workforce, lack of investment in the Information Technology sector specific for this purpose, absence of a plan or program for maintenance, absence of specific actions in maintaining structured steel constructions, lack of technical staff for the preparation of inspections, reports and memorial, among others. Faced with this disturbing reality, this study aims to propose guidelines for maintenance of the buildings of public educational institutions, in order to improve the quality of maintenance of these buildings. The methodological approach adopted is the exploratory case study. An investigation of 11 public educational institutions of Minas Gerais is performed. The main contributions of the work refer to the proposition of maintenance management guidelines such as the knowledge of the buildings, the management through software and maintenance program to be used and replicated for other educational institutions of similar characteristics.
\end{abstract}

Keywords: Management; Building management; Public buildings; Maintenance management guidelines.

Resumo: As edificações públicas de ensino necessitam de um planejamento para a conservação e manutenção de seus diversos sistemas e instalações. Na prática, constata-se que existem grandes desafios na gestão da manutenção das Universidades Federais do Estado de Minas Gerais que envolvem a falta de recurso financeiro, mão de obra desqualificada e insuficiente, falta de investimento no setor de Tecnologia da Informação específico para esse fim, ausência de plano ou programa de manutenção, ausência de ações específicas na manutenção de construções estruturadas em aço, ausência de equipe técnica para elaboração de vistorias, laudos e memorial, entre outros. Diante dessa realidade preocupante, o presente estudo visa a propor diretrizes de manutenção para as edificações de instituições de ensino públicas, afim de melhorar a qualidade da manutenção desses edifícios. A abordagem metodológica adotada é o estudo de caso exploratório. É realizada uma investigação das 11 instituições de ensino públicas de Minas Gerais. As principais contribuições do trabalho referem-se à proposição de diretrizes de gestão da manutenção como por exemplo, o conhecimento das edificações, o gerenciamento por meio de software e o programa de manutenção, a serem utilizadas e replicadas para outras instituições de ensino de semelhantes características.

Palavras-chave: Gestão; Manutenção predial; Prédios públicos; Diretrizes de gestão da manutenção.

Received June 3, 2018 - Accepted Oct. 9, 2019

Financial support: None.

This is an Open Access article distributed under the terms of the Creative Commons Attribution License, which permits unrestricted use, distribution, and reproduction in any medium, provided the original work is properly cited. 


\section{Introduction}

Institutions of Higher Education are physical instruments used in the production of knowledge and the development of people; they are used in the formation of future leaders, headman of industries, entrepreneurs, scientists, engineers, managers, etc. and because of this, they need to work with maximum performance throughout its useful life (Beltrame \& Moura, 2009; Olanrewaju et al., 2010; Haniza Fakhrudin et al., 2011).

Many studies demonstrate a direct relationship between the performance of students and the quality or lack of quality of the constructed physical spaces, without the conservation of their built environments, with architectural designs without quality or poorly executed and with no maintenance of its existing buildings (Taralli, 2004; Kowaltovski \& Deliberador, 2011; Paes \& Bastos, 2014). Few works explore the management of school buildings maintenance, especially in the case of public universities buildings (Ornstein \& Martins, 1997; Vieira, 2014).

According to the US Department of Education, a school must have a planned facilities maintenance program, managed and effective. And yet, schools receive investment from the government and because of that, maintenance planning can not be negligent or wasted, as this would discourage public investment in the educational system in the future (Lavy \& Bilbo, 2009).

In the most developed countries, to maintain a property heritage in good conditions, whether it is public or not is a cultural issue and routine, being that, hiring a service company to develop a maintenance plan is an activity that is done naturally. Each 1 euro or dollar (or other currency) spent in the construction phase of a building, there is 5 euros/dollars that are spent for its operation during 30 years (Vieira \& Cardoso, 2005; Olanrewaju et al., 2012, Vieira, 2014).

In Brazil, however, feature prominently minimal actions of conservation and preservation, and the almost complete lack of maintenance with inappropriate practices, still based on ineffective corrective actions in the vast majority of cases, and in insufficient preventive actions (Abreu, 2012).

Lessa \& Souza (2010) observes that a program of management of the maintenance of a building minimizes budgetary impacts in the future, avoids accidents besides deteriorations of many kind. However, they state that in order to do so it is essential to be done and followed by qualified personnel with technical administrative knowledge in order to maintain the performance of the building, the safety and the comfort of the user.

It is important to point out that a Plan or Maintenance Program in public buildings, whether they are devoted to education or not, allows to guarantee higher quality in preserving the public good itself and therefore generates greater economy and preserves resources. It is a continuous process that needs to be replenished with information aiming its improvement (Carlino, 2012).

Each type of construction or building production system, so to speak, needs to be analyzed with its particularities and lacks a specific maintenance planning that meets its needs and specificities. No matter how good the planning, the project and execution of a building, all of it, without exception, lack a maintenance planning over the years (Cupertino \& Brandstetter, 2015).

The investment of public resources for the maintenance of its buildings is always justifiable given the fact that the government is investing in its assets, making its performance and useful life improved. It is important, but not easy for managers or building maintenance managers of public institutions to raise awareness among 
administrators about the creation of a preventive maintenance program, planned and organized, with resources forecasting as a way to preserve the institutional public patrimony (Carlino, 2012; Araújo, 2015).

For Olanrewaju et al. (2012) the purpose of maintenance is to optimize and maximize the functional, economic and aesthetic values of the building so that they can contribute with the lowest possible costs. The goal of maintenance management is to continuously operate aged buildings, while meeting the growing requirements of standards and regulations and optimizing costs with their integrity.

According to Frangopol et al. (2012), to maintain or improve the reliability and functionality of these structures it should be adopted an integrated planning of management, suitable to the whole life cycle of the building. The biggest hindrance to the adoption of such a concept is a cultural problem of not carrying out maintenance on the buildings. Today, administrators responsible for the conservation of the buildings comprehend, as maintenance concept, only the execution of minimum services that enable the systems of the building not to collapse, not understanding the idea of preventive maintenance. With this, the term maintenance is associated with the idea of unexpected expenses, and not to the idea of heritage preservation (Vieira, 2015).

In this context, the present work presents an analysis on the management of building maintenance of the Federal Universities of Minas Gerais, from 11 case studies, verifying their needs and failures, and suggesting improvement mechanisms. As an objective, there's the proposal of guidelines as tools of management for the maintenance of the existing buildings in these 11 public educational institutions of Minas Gerais: proposing a model of management of maintenance. For a better identification of the proposed guidelines it is returned to the specialized literature in the field of building maintenance and maintenance tools for management for a wider theoretical background (Gomide, 2008; Bahia, 2009; Moraes, 2012; Cardoso, 2013). In the literature review it can be observed some of the works that suggest guidelines such as tools for the improvement of the buildings, however, the majority of these works are geared to the planning and design phase, as well as, for social interest housing (Brandão, 2011; Carraro \& Dias, 2014; Nogueira et al., 2018). The originality of the research lies particularly in its object of analysis, the public buildings belonging to Federal Universities, and particularly, those located in the state of Minas Gerais.

\section{Theoretical framework}

\subsection{Building maintenance}

All buildings begin to age from the moment they are completed and putted into use. Maintenance is therefore necessary throughout the period when the building remains in use or in occupation and to ensure its optimum performance throughout its life cycle.

Pitt et al. (2016) define maintenance as an effort of the administration to keep a physical asset, or restore it to a condition that enables it to perform a required function. Managers consider the preventive planned maintenance a prudent investment, resources that are invested today, are lower in the future and ensure the increase of the useful life of the property.

The activities of building maintenance receive different classifications, and in Table 1, presents those commonly used within a management plan, and their main characteristics (Kardec \& Nascif, 2006; Abreu, 2012). 
Table 1. Types of building maintenance.

\begin{tabular}{ll}
$\begin{array}{l}\text { Corrective } \\
\text { maintenance }\end{array}$ & $\begin{array}{l}\text { Less recommended, unplanned failure, unfeasible costs to } \\
\text { unexpected fixes. }\end{array}$ \\
\hline $\begin{array}{l}\text { Preventive } \\
\text { maintenance }\end{array}$ & $\begin{array}{l}\text { Reduces the incidence of corrective maintenance in the future, less } \\
\text { probability of failures. }\end{array}$ \\
\hline
\end{tabular}

Source: Barbosa \& Pusch (2011).

The corrective maintenance is older and conservative, characterizing itself by the reaction to a flaw, defect or malfunction in the building, since in this type of maintenance there is no planning or programming. Preventive maintenance, in turn, requires planning and discipline, and on the other hand decreases the shortcomings and costs in the medium and long term (Xenos, 2004; Shareghi \& Faieza, 2011; Vieira, 2015). Contrary to what occurs in the industry, the preventive maintenance of buildings is not limited to the halting of the production process, perhaps, a time of unavailability of use of that particular space (Correia \& Dias, 2016).

One of the main tools used in the management of building maintenance is the maintenance program determining the activities within a period of time, in the short, medium and long term. This program includes workers, companies, competent workforce to exercise that function, the data or documents that need to be gathered before and after performing that activity for control purposes, which materials and equipments are necessary to accomplish that activity, all of this released in a suitable computerized system of planning (ABNT, 2012).

In the maintenance plan, the activities are distributed in relation to the need and for a period of time and classified by Cardoso (2013) as presented in Table 2.

Table 2. Building maintenance activities.

\begin{tabular}{ll}
\hline Routine activities & $\begin{array}{l}\text { Does not cause risk, conservation activities, parts exchange and } \\
\text { minor repairs. }\end{array}$ \\
\hline Periodic activities & Related to preventive maintenance, follows schedule \\
\hline Emergency activities & Demand high costs, variable teams \\
\hline
\end{tabular}

\subsection{Maintenance tools}

Standard NBR 5.674 (ABNT, 2012) settle some tools for building maintenance, guiding to the creation of cited maintenance guidelines, which are: building inspection, maintenance planning, information and documentation systems and maintenance management. The building inspection is understood as an overhaul carried out in the building in order to raise various aspects and examine its state of conservation, raising possible pathologies and understanding the generalities of the building (IBAPE, 2005; Castro, 2007; Pujadas, 2007). Maintenance planning refers to a strategy of tasks managed within plans of short, medium and long term, and requires a detailed forecast of activities (Gomide, 2008; ABNT, 2012; Moraes, 2012).

The information and documentation systems are maintenance softwares specifically created to store important data within the process of maintenance management and used by professionals working in the building area. It is provided for example, check-lists, reports and control of costs and resources such as workforce and equipments (Morilha, 2011; Shareghi \& Faieza, 2011; Moraes, 2012). 
Finally the procedure for the management of building maintenance consists of the planning of indispensable activities of maintenance, occurrence period, the execution responsible and required resources, being that the responsibility of a building manager (Bahia, 2009; Almeida \& Vidal, 2009; Silva, 2014). According to Silva (2014) it is only possible to manage something with a broad knowledge of that object. Therefore the creation of a database is paramount for a manager. Technical memory allows more assertive decision-making.

In addition to the tools mentioned in the standard rule, Gomide et al. (2014) also present some documents that should be analyzed, when available, which are: the manual of use, operation and maintenance of the building, intervention records books, reports of complaints from users and technical manuals. Furthermore, according to the authors, the maintenance planning should take into account: the typology of the building, existing systems and equipment, the expected useful life, the flaws found in the inspections, the record of previous maintenance performed, corrective and preventive action recommendations, the priority scale of interventions and budget forecasting.

To Othuman (2017a) the life of a building can be extended as long as it is based on proper maintenance. In addition, the value of a building declines with its aging unless it is submitted to frequent maintenance.

An inquiry to be posed is whether managers in the field of building maintenance use the procedures defined by the existing legislation and norm and whether the resources allocated in the budgets are sufficient for the implementation of necessary procedures for building maintenance, especially public buildings of education.

\subsection{Management of maintenance of the universities}

According to Silva (2014), maintenance management and buildings operations become an investment to give the property the necessary conditions for its operation, ensuring the operation of the facilities with safety and health. A well planned and executed maintenance tends to contribute to the reduction of the operational costs of the enterprise, in addition to ensuring the safety and health of those who use it (Othuman, 2017b).

This means programming the work, providing resources (people, materials and tools) and setting the appropriate time. This is the part of the maintenance planning that, similarly to the production, has its Maintenance Master Plan, contemplating a vision with a slightly larger horizon (months), and its Scheduled Maintenance, covering in details the daily activities (Worthing et al., 2003).

Similarly, the use of computerized systems for maintenance management, due to the huge amount of data that needs to be manipulated and interpreted to generate useful information, becomes practically mandatory. Flexibility and the ability to interface with other information systems are critical success factors that need to be evaluated when choosing a Maintenance Management System. It is believed that an effective maintenance management model should appreciate all these points.

For the implementation of a software to support maintenance management of assets it is necessary to create a database and gather information. There is a need to seek information from compatible and reliable sources with the maintenance processes. These sources of information are the beginning of the procedure for deploying a computerized system.

The evaluation strategy for the management of building maintenance should proceed the following stages: identification of the maintenance strategy type; verification of identified strategy consistency with the expectations of the users; execution of building inspection for verification of non-compliance techniques of use and maintenance; analysis of the documentation relating to the building to complement 
data provided by the inspection and identification of failures in maintenance contracts with third parties; assessment of the maintenance team regarding their education, sizing and capacity to accomplish determined actions; assessment of the costs of maintenance and finally evaluation of the quality of the maintenance employed (Araújo, 2015; Kwon et al., 2011).

Odediran et al. (2015) shows that the school environment, with all its facilities have a very large burden in determining the quality of the education, this means to say that poor infrastructure conditions become obstacles in the implementation of this goal. Challenges associated with aging and the expansion of educational facilities are identified by leaders of higher education, in developed economies, as one of the determinants of academic and research performance (Olanrewaju, 2012).

The maintenance of new buildings, renovation and modernization of old ones require considerable expertise and commitment of human and material resources. This is because the changes in climatic conditions and lack of maintenance culture are responsible for the aging and deterioration of buildings and educational equipments (Lind \& Muyingo, 2012). However, the majority of educational administrators/managers who constantly use the educational facilities do not have the knowledge of planning the maintenance of these facilities. An effective plan of management should begin with the educational philosophy that meets the needs of the individual in a dynamic knowledgebased economy. To Yik et al. (2010) the building maintenance policy must be articulated in three essential elements: the choice of a maintenance strategy, the definition of the maintenance pattern and allocation of resources for maintenance.

The need of management in university facilities cannot be underestimated. The responsibilities of management require collective efforts and processes of management that involve planning, organization, decision making, leadership, coordination and control (Fianchini, 2007; Othuman, 2017b).

Given the foregoing previously submitted, the references mentioned guides the creation of the guidelines and are highlighted in Table 3.

Table 3 - Maintenance tools used for creating the guidelines

\begin{tabular}{|c|c|c|}
\hline Description of tools & Source & Base concept \\
\hline $\begin{array}{l}\text { Collection of information of the building: property } \\
\text { type, age, construction pattern, area, use, } \\
\text { operation, used construction system, existing } \\
\text { equipments etc. }\end{array}$ & $\begin{array}{l}\text { Gomide } \\
(2008)\end{array}$ & \multirow[t]{3}{*}{ Knowledge of the building } \\
\hline $\begin{array}{l}\text { Control procedures and routine maintenance of } \\
\text { the building over time, available documentation, } \\
\text { records. }\end{array}$ & $\begin{array}{l}\text { Gomide } \\
(2008)\end{array}$ & \\
\hline $\begin{array}{l}\text { Building inspection, verification of anomalies and } \\
\text { state of conservation, reports and check-lists. }\end{array}$ & $\begin{array}{l}\text { Barbosa \& } \\
\text { Pusch } \\
(2011)\end{array}$ & \\
\hline $\begin{array}{l}\text { The importance of information storage from the } \\
\text { conception to its commissioning is of extreme } \\
\text { importance to the maintenance of the building } \\
\text { useful life. }\end{array}$ & $\begin{array}{l}\text { Moraes } \\
(2012)\end{array}$ & \multirow[t]{2}{*}{$\begin{array}{l}\text { Management } \\
\text { software }\end{array}$} \\
\hline $\begin{array}{l}\text { It is observed that softwares, in almost their } \\
\text { entirety, are still exclusively developed to attend } \\
\text { equipments. }\end{array}$ & $\begin{array}{l}\text { Morilha } \\
(2011)\end{array}$ & \\
\hline $\begin{array}{l}\text { The maintenance planning must be set on short, } \\
\text { medium and long terms. }\end{array}$ & $\begin{array}{l}\text { Gomide } \\
(2008)\end{array}$ & \multirow[t]{2}{*}{ Maintenance program } \\
\hline $\begin{array}{l}\text { In the planning process maintenance priorities } \\
\text { are set. }\end{array}$ & $\begin{array}{l}\text { Moraes } \\
(2012)\end{array}$ & \\
\hline
\end{tabular}




\section{Methodology}

The research strategy adopted is the qualitative research with case study, which is not based on numerical representativeness, but, mainly, to understand a social group or organization in a profound manner. It is therefore concerned with aspects of reality that perhaps cannot be quantified, but understood and explained dynamically with social relationships (Gerhardt \& Silveira, 2009). As to the goals, it is a descriptive research, with two sources of information, in addition to literature review: semistructured interviews and documentary. For data analysis it was used the technique of thematic analysis.

This work uses the analysis of the building maintenance commonly employed in Minas Gerais Federal Universities. For this, the population comprises eleven federal universities, belonging to the State of Minas Gerais in the southeast region, which has the largest concentration of federal universities in the country. From the general presentation of the framework for existing maintenance in the Universities it is possible to reach the main difficulties experienced, the tools, techniques and used softwares, types of existing constructions, and after this reading, identify the reality of building maintenance applied currently in the eleven Federal Universities of Minas Gerais State. In Figure 1, the flowchart outline the main steps of the research.

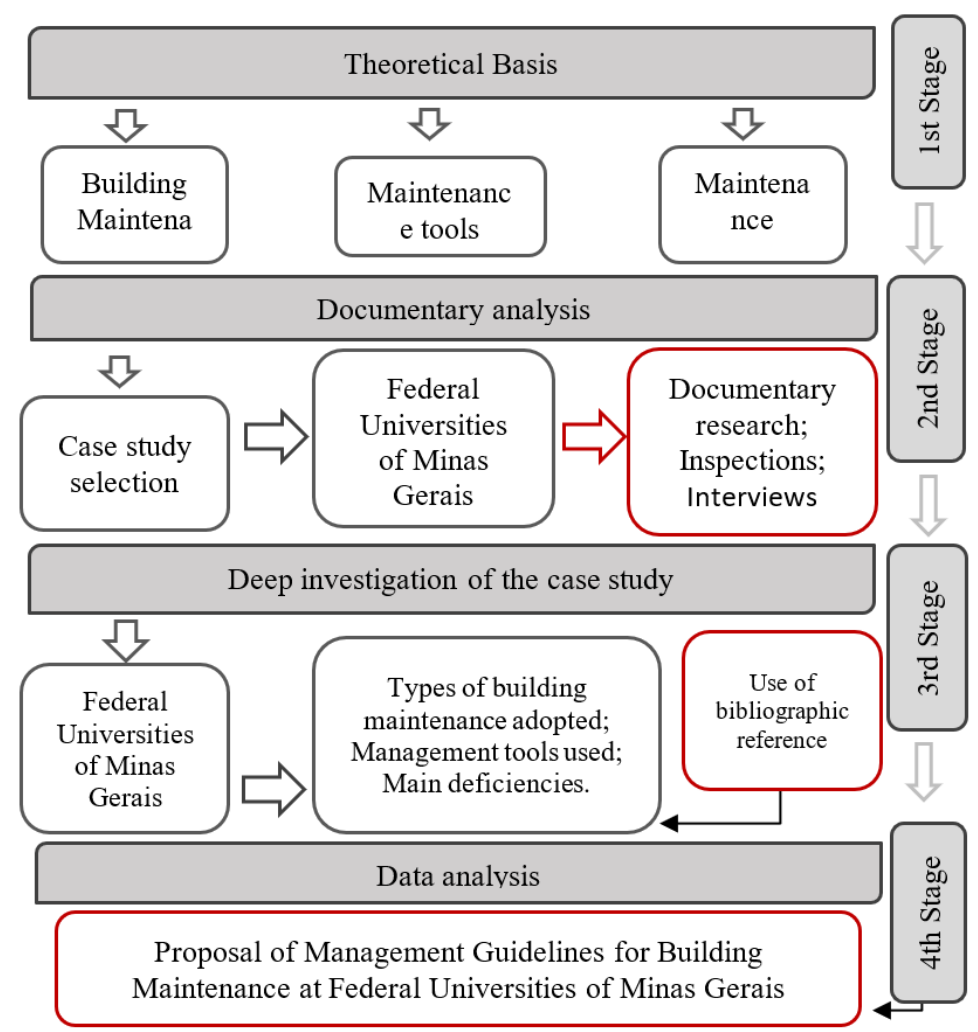

Figure 1. Outline of the research stages. Source: Cupertino \& Brandstetter (2015).

It is worth mentioning that it is adopted the technique of content analysis aimed to apprehend the perceptions, opinions and experiences lived by the organizational authors (David et al., 2011). The main documents analyzed in each University includes: 
- Institutions websites;

- The building maintenance manual of some campuses;

- Management reports;

- General regiments;

- Institutional development plans;

- Internal reports and resolutions.

In the first stage, it was consulted a bibliographical reference that involves related themes to the research, understanding the definitions of building maintenance, its phases and processes, the basic tools cited by the authors for an effective management of this maintenance and the current operation of the maintenance management of public universities of Minas Gerais.

In the second stage, objects of the case study were defined, selected Universities were all Federal Universities in the State of Minas Gerais, totaling 11 (eleven) institutions. The documentary analysis and interviews made permit to visualize an overview of the management of building maintenance in these institutions.

Interviews are conducted personally, recorded and transcribed. These interviews were made with key persons: architects, engineers, technicians, managers, and employees responsible for the maintenance sector of the infrastructure of studied Universities, in the period of August 2015 to July 2016.

In the third stage, there is a deepening of studies aiming at achieving the major management difficulties experienced by the universities, to do a reading of the current configuration of the system of building maintenance adopted by the universities, the maintenance tools employed, the techniques and softwares used, existing construction typology, and after this reading, identify the reality of building maintenance applied during the research period (2015-2016). The goal is to collect information that clarifies the maintenance management employed in these universities and possible failures in the process. Collected data is analyzed based on studied literature.

By the lifting of all these informations, guidelines are established, in the fourth stage of the research, in order to guide professionals responsible for the function of building maintenance. The proposal of guidelines to the maintenance activities to be used is constructed based on the interviews conducted, in the main needs raised by these professionals (maintenance management actions recommended by them) and reviewing of the literature, especially taking into account the maintenance tools mentioned by several authors, which are: building inspection, the use of a computerized management system capable of managing the collected data and creation of a maintenance program of the universities through maintenance plans of each building. The creation of the guidelines, therefore, is based on the proposal to use the preventive maintenance, planned and not corrective, usually employed on these days. It is expected that these guidelines can be replicated to other Federal Universities as well as other public buildings.

According to Machado et al. (2015) management and maintenance management become crucial elements to be studied scientifically assisting in the strategic character of maintenance activities. 


\section{Analysis and interpretation of results}

To achieve effective results in building maintenance of educational institutions buildings, it is proposed guidelines based on three main pillars as presented in Figure 2. According to Moraes (2012) a maintenance plan must contain data about the existing property consisting of the building that will be parsed, and where it will be executed the maintenance procedure (first pillar). Softwares are directed to the management. And, with the information record, provide check-lists; reports (failures occurrences, equipment availability, costs,labor, etc.) as well as stock control, administration and costs (second pillar). The existence of a Maintenance Program (third pillar) in public agencies is based on the assurance of quality in the provision of services, not only efficient but effective services, while preserving the public assets and, consequently, reducing unnecessary expenses (Carlino, 2012).

Some of the methods and tools used in conceiving the guidelines of this paperwork appear in some surveys as resources for a quality maintenance, which are: regular inspection practices; preventive maintenance plans; record of maintenance actions; use of computerized systems for maintenance management; database with diverse information (Flores, 2002; Vieira, 2003; Vieira \& Cardoso, 2010).

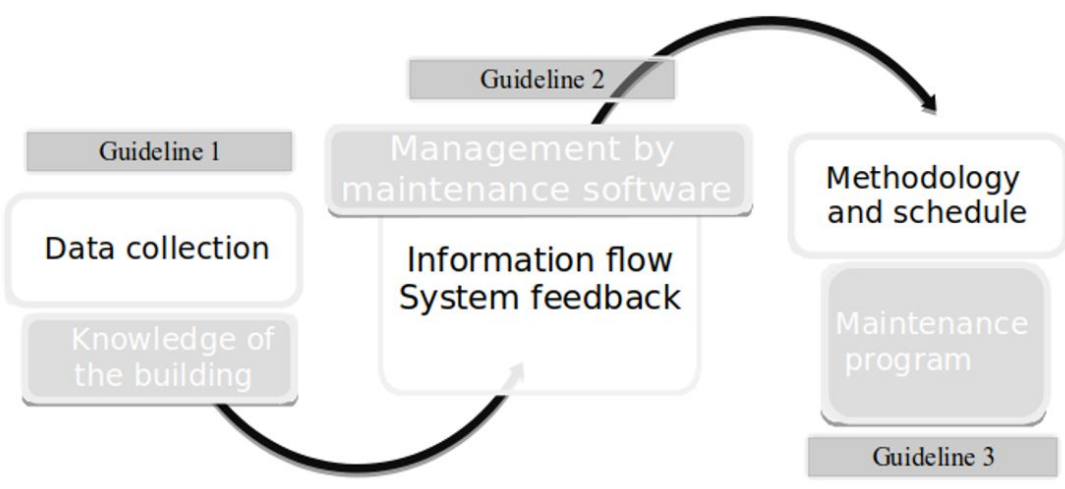

Figure 2. Guidelines based on three pillars. Source: Author.

Knowing the buildings of Federal Universities does not mean just to know that this is the building of Education and that the School of Pharmacy. It is crucial to raise all the possible data from each existing building. The strategies of Guideline 1 are detailed in Figure 3. According to the interviews conducted, there is no such detailed knowledge and especially computerized of all existing buildings at the Universities.

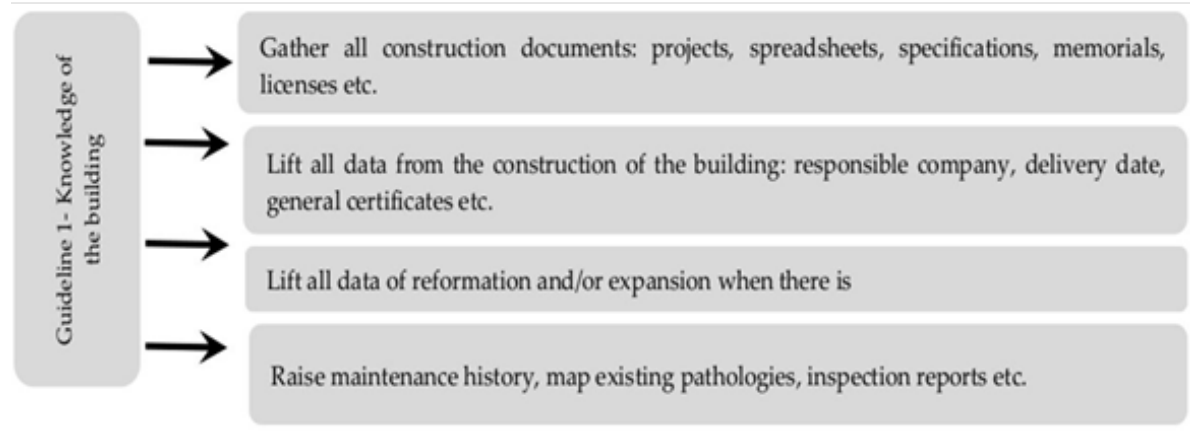

Figure 3. Strategies of the Guideline 1. Source: Author. 
Contrary to what is seen about references on maintenance softwares, it is proposed with the Guideline 2 the creation of a system of information geared to buildings, and not equipment or production lines. When thinking about a specific program to manage maintenance activities it must be thought too that the information provided within that is able to make this preventive maintenance management efficient.

According to Morilha (2011) some points need to be considered when thinking about implementation of a computerized maintenance system: the need for training the team that feeds it, greater involvement of managers in the register of this system and in the reading of generated reports and highly experienced team in Information Technology (IT).

To Vieira (2003) the adequate training of human resources is essential, since the use of a computerized system of maintenance requires appropriate skills to the reading and analysis of the collected data. Maybe the fact that most universities outsource their maintenance service is a hindrance to this training, bearing in mind, in particular, the turnover of employees. Some authors appropriately remind that universities buildings maintenance, not only in Minas Gerais but in all Brazil, occurs through the outsourced team and, nevertheless, none should be performed with less accuracy or quality (Pinto et al., 2014).

According to collected information from the interviews, only one of the eleven surveyed institutions came to inspect their buildings, to map the existing pathologies and to verify the conservation state of those. However, they do not have a suitable software to store and work with this information and without a maintenance plan, the material remains filed.

Figure 4 shows the Guideline 2 strategies.

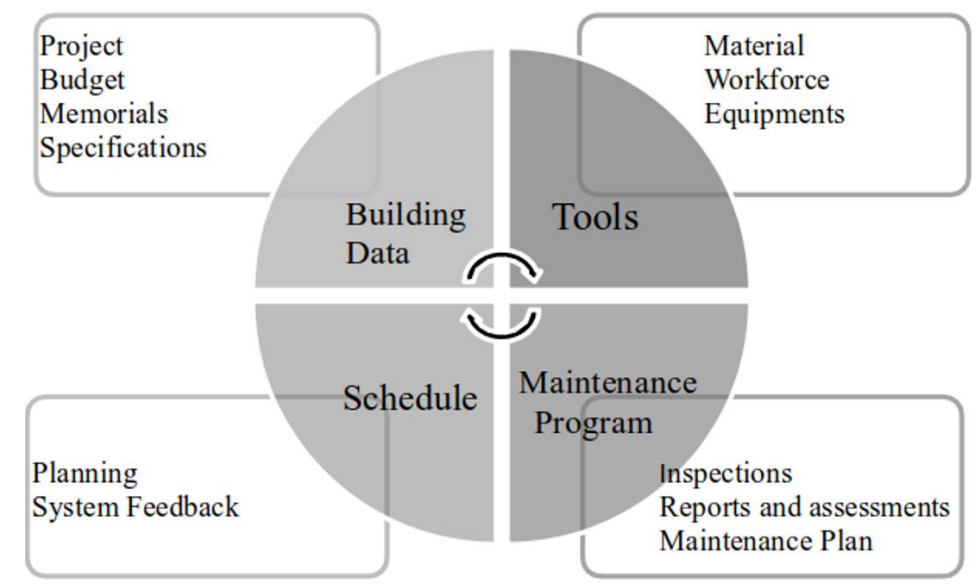

Figure 4. Guideline 2 strategies. Source: Author.

Inside the Building Data block is included all the details already mentioned in Guideline 1. Regarding the necessary tools for the execution of the preventive maintenance services the three main listed are: the equipment, materials and available workforce. These tools are thought taking into consideration that the preventive maintenance activities are carried out internally, by outsourced personnel or permanent staff, but without the pretense of bidding for its execution. Table 4 presents the necessary and corresponding data to each of the tools. 
Table 4. Tools information.

\begin{tabular}{ccc}
\hline Equipment & Workforce & Materials \\
\hline Availability & Employee data & Stock/availability \\
\hline Use conditions & Specialty & Targeting of use \\
\hline Use and operation manual & Responsible team & Technical Specification \\
\hline Technical Specification & Outsourced or not & Updated cost \\
\hline Updated cost & Work schedule & Supply Company \\
\hline Supply Company & Vacation schedule & \\
\hline Expected useful life & Licenses & \\
\hline
\end{tabular}

Source: Author.

Each one of the University buildings may have their complete data and for each one of them, a maintenance program, which is detailed in Guideline 3. The intersection of all the information makes it possible to open the fronts of preventive maintenance for the existing workforce. After planning activities in time (whether a week, month or year) a schedule is done with the main maintenance activities to be implemented and followed, and could be reevaluated, modified and provided feedback into the system.

For control and knowledge of the managers, it can be created a window within the preventive building maintenance software about financial resources for maintenance, raising data on monthly and annual expenditures, managing the corrective maintenance and checking the decrease along the deployment of the preventive maintenance, developing graphs and tables that ratify the consolidated economy in the various services and attesting the efficiency of that management.

Guideline 3 is formed by the maintenance program. The plan or program of maintenance needs to anticipate and detail: actions, responsibilities, priorities, time spent on execution of the services, materials and tools needed, work methods, accomplishments schedule and budget forecasts.

According to research done in countries such as the United States of America (USA), United Kingdom (UK), Canada or Australia there is a clear concern with the development and implementation of plans of building maintenance in their Universities and it comes with the direct participation of each institution in its preparation (Hauer et al., 2000; Vieira, 2003).

To start the work of the maintenance program, it is essential to know the conservation status of each of the building that belong to the Federal Universities of Minas Gerais, conducting inspections and making a physical assessment of the diverse construction systems. After the plan creation, the inspections execution dates can be scheduled and compared by identifying the development of the conservation status of buildings from performed interventions. According to what was seen in the interviews, there was hardly a mapping of pathologies on the existing buildings of Federal Universities through scheduled inspections.

In a study conducted in Malaysia about the maintenance of their universities it is noted that the inspection of a building happens in part of them in order to set the planned expenditure for the following year, but a considerable number of Universities, most of them, do not have this knowledge. As a large part of the maintenance is outsourced, as the case of Universities studied in this work, the maintenance of Universities in Malaysia is essentially corrective (Olanrewaju, 2012).

The strategies used in Guideline 3 are presented in Figure 5. 


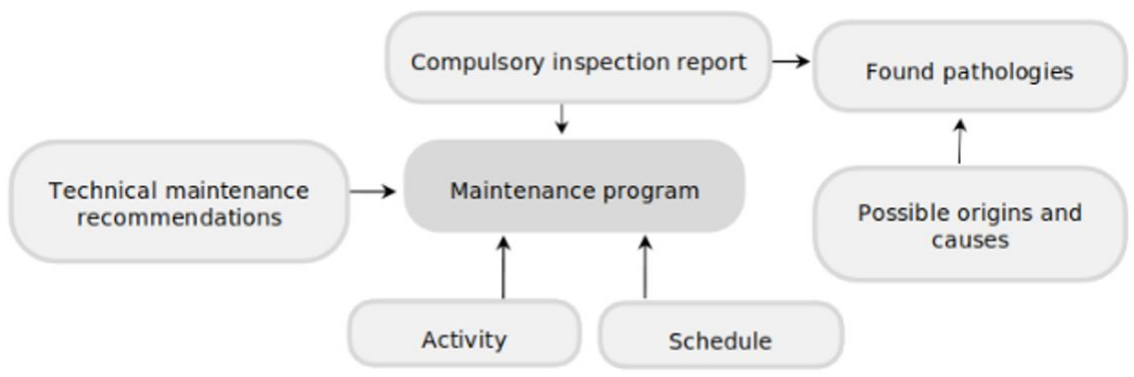

Figure 5. Strategies of Guideline 3. Source: Author.

The inspection report must be mandatory in all existing buildings in order to ascertain the conservation status of the various systems and components of the building: closures, cover, structure, frames, floors, various facilities, to identify and later map the various pathologies possibly installed. Of those same pathologies it can be found possible origins and causes.

In possession of the inspection report, along with the knowledge of mentioned pathologies, recommendations of maintenance techniques are suggested being that in the short, medium and long term. These recommendations for each system or component of the building demand a series of activities that need to be fulfilled within a time limit (schedule). In Table 5 are presented some of the maintenance actions suggested by the interviewees that can be carried out in the buildings, particularly those that are structured in steel.

Table 5. Technical recommendations for maintenance in steel structures.

Perform continuous monitoring, where in addition to the visual assessment, were made suitable non-destructive testings.

Scraping and sanding damaged paint or corrosion points; cleaning for removal of impurities and material powder coming from the previous step; application of anticorrosive primer; painting with enamel paint.

Envelopment of the base of the pillars in steel with concrete, creating a protective layer and reinforcing the structure in that region in cases of structural bases corrosion for soil moisture.

Hiring of periodic consulting for professional review of structural behavior of built buildings.

Development of a plan of technical inspection to the assessment of the conditions of facilities and monitoring the conservation status of these.

When there is corrosion, scrubbing with steel brush, then applying a material to remove this layer of existing rust, after that apply primer and automotive paint in the structure as a whole.

Detailing of junctions with the structure of reinforced concrete, and special care with the varying expansion of materials, reinforced concrete, masonry and steel structure.

Waterproof the interface of steel frame with masonry.

Source: Author.

To work properly, although within a large management system of preventive maintenance, each building must have its own maintenance program from their technical characteristics, their current conservation status and its mapped pathologies.

A maintenance management model is only efficient and effective when Universities put their needs within the process, and abandon the traditional strategies of a character basically corrective (Campos \& Márquez, 2009; Khamidi et al., 2010). 


\section{Final considerations}

It is possible to observe that today there is no planning for a preventive maintenance, which could decrease expenditures and improve considerably the useful life of the buildings. Maintenance applied in the buildings of the Federal Universities of the state of Minas Gerais, has a basically prompt character, correcting faults that are presented in the last degree, which earns the title of "urgent". With so, some buildings continue to present visible pathologies, but not raised by the managers and therefore not eliminated, precisely because there's not a systematization of the needs and a building maintenance program.

It is crucial to raise all the possible data of each existing building, such as construction date, materials and techniques employed, extensions, reforms, existing pathologies, recurring problems, interventions made and their respective dates, uses, failures etc. It is observed through the Federal Universities interviewees of the State of Minas Gerais, linked to the sector of building maintenance, that they don't have all this information about the existing buildings and, without this knowledge, it becomes practically impossible to manage possible preventive maintenance measures.

Faced with the existing literature on the subject and based on the case studies, it is found that maintenance management in Universities of Minas Gerais is fundamentally corrective, generating, often, the solution of failures with high and unexpected expenses. In this context, the public money, scarce in reality, leaves, many times, the chance to be well spent.

The maintenance guidelines (the building knowledge, the management through maintenance software and maintenance program), the final product of this research, allow rethinking the used management model. The proposal seeks to present mechanisms for the execution of preventive maintenance, more efficient, with the aim of diminish the appearance of unforeseen collapses in the building. The proposition of these guidelines contributes to the advancement of knowledge about the systematization of the maintenance management process, especially when it refers to the public universities buildings, hardly explored in much of the research in this field. Also contributed to a discussion about the management of the maintenance performed on the buildings of federal universities and on the failures and difficulties encountered in the process.

The first guideline, building knowledge, shows how important it is to create a data collection on any building belonging to Universities, through a breakdown of information, mapping of their conservation status, effectively managing preventive actions. The second guideline, management through maintenance software, contributes to the storage of these collected data facilitating the targeting of information and enabling control of people, materials and tools. The third guideline in turn, the maintenance program, highlights the importance of maintenance prevention, a fact that hardly happens in Universities today. It shows how essential it is to anticipate actions, responsibilities, dates of interventions and consequently budget forecasts, giving a higher quality of management.

In addition to the originality in the proposal of the guidelines, the research contributes to a collection of information regarding the maintenance management of public university buildings in order to provide correct and accurate records that can be useful for those in the decision making management.

In the Educational Institutions studied there really isn't a preventive maintenance plan to be followed, for none of the existing buildings, whether these buildings systems are structured in steel or conventional, in concrete or masonry. The culture used by 
managers is still very limited to corrective maintenance. It is intended with the proposed maintenance guidelines, to display paths or possibilities that can be used or reconsidered later and thus generate a contribution to Public Administration. To work properly, although within a large management system of preventive maintenance, each building must have its own maintenance program from their technical characteristics, from their current conservation status and its mapped pathologies. Some buildings present greater needs and require more labor, more materials and tools, and higher cost, while others, with less damages or even less time of existence require more simple maintenance. But all need to be part of this macro planning of preventive maintenance.

It is concluded that there are many responsible professionals that assume the function of work for the maintenance of Universities every day, managing scarce financial resources to perform urgent corrective maintenance that do not bother to arise in function of all of the challenges already discussed.

In respect to those professionals and the entire academic and administrative community which uses the universities buildings over the years, it is justified raising the issues presented here and the importance of discussing solutions even though punctual, but significant, capable to generate a movement towards an improvement of those buildings and consequently of the daily routine of those who use them.

\section{Acknowledgements}

The authors acknowledge the support of the Universidade Federal de Ouro Preto and Instituto Federal de Educação, Ciência e Tecnologia de Minas Gerais..

\section{References}

Abreu, W. G. (2012). Identificação de práticas sustentáveis aplicadas às edificações (Dissertação de mestrado). Universidade Federal Fluminense, Niterói.

Almeida, C. S., \& Vidal, M. C. R. (2009). Gestão da manutenção predial. Rio de Janeiro: Gestalent.

Araújo, P. G., No. (2015). A manutenção predial nas edificações públicas, um estudo sobre a legislação. E\&S - Engineering and Science, 1, 3, 85-93. http://dx.doi.org/10.18607/ES20153255.

Associação Brasileira de Normas Técnicas - ABNT. (2012). NBR 5.674: Manutenção de edificações - Requisitos para o sistema de gestão de manutenção. Rio de Janeiro: ABNT.

Bahia. Governo do Estado. (2009). Manual de gestão predial. Salvador: Secretaria da Administração: Superintendência de Serviços Administrativos.

Barbosa, P. B., \& Pusch, J. (2011). Da intenção de projeto ao uso do edifício: a busca da excelência profissional. Curitiba: Programa de Excelência em Projetos CREA-PR.

Beltrame, M. B., \& Moura, G. R. S. (2009). Edificações escolares: infraestrutura necessária ao processo de Ensino e aprendizagem escolar. Revista Travessias, 3(2), 1-15.

Brandão, D. Q. (2011). Disposições técnicas e diretrizes para projeto de habitações sociais evolutivas. Ambiente Construído, 11(2), 73-96. http://dx.doi.org/10.1590/S167886212011000200006.

Campos, M. L., \& Márquez, A. C. (2009). Review, classification and comparative analysis of maintenance management models. Journal of Automation, Mobile Robotics \& Intelligent Systems, 3(3), 110-115. 
Cardoso, M. R. (2013). Manutenção predial: verificação de indicadores de performance como instrumento de avaliação de empresa terceirizada. Universidade Federal do Rio Grande do Sul, Porto Alegre.

Carlino, A. E. (2012). Melhorias dos processos de manutenção em edifícios públicos (Dissertação de mestrado). Universidade Federal de São Carlos, São Carlos.

Carraro, C. L., \& Dias, J. F. (2014). Diretrizes para prevenção de manifestações patológicas em Habitações de Interesse Social. Ambiente Construído, 14(2), 125-139. http://dx.doi.org/10.1590/S1678-86212014000200009.

Castro, U. R. (2007). Importância da manutenção predial preventiva e as ferramentas para sua execução. (Monografia). Escola de Engenharia, Universidade Federal de Minas Gerais, Belo Horizonte.

Correia, R. F., \& Dias, A. (2016). Modelagem matemática para otimização de periodicidade nos planos de manutenção preventiva. Gestão \& Produção, 23(2), 267-278.

Cupertino, D., \& Brandstetter, M. C. G. O. (2015). Proposição de ferramenta de gestão pósobra a partir dos registros de solicitação de assistência técnica. Ambiente Construído, 15(4), 243-265. http://dx.doi.org/10.1590/s1678-86212015000400049.

David, M. V., de Castro, L. G., Jr., Sanábio, M. T., \& Mucci, D. M. (2011). Transformações na educação superior no Brasil e seus impactos na relação Universidade -Sociedade: o caso de três universidades federais mineiras. In 35th Annual ANPAD Meeting. Maringá: ANPAD.

Fianchini, M. (2007). Fitness for purpose: a performance evaluation methodology for the management of university buildings. Facilities, 25(3/4), 137-146. http://dx.doi.org/10.1108/02632770710729728.

Flores, I. S. (2002). Estratégias de manutenção - elementos da envolvente de edifícios correntes (Dissertação de mestrado). Instituto Superior Técnico, Universidade Técnica de Lisboa, Lisbon, Portugal.

Frangopol, D. M., Saydam, D., \& Kim, S. (2012). Maintenance, management, life-cycle design and performance of structures and infrastructures: a brief review. Structure and Infrastructure Engineering: Maintenance, Management, Life-Cycle Design and Performance, 8(1), 1-25. http://dx.doi.org/10.1080/15732479.2011.628962.

Gerhardt, T. E., \& Silveira, D. T. (2009). Métodos de pesquisa. Porto Alegre: Editora da UFRGS. Universidade Aberta do Brasil - UAB/UFRGS.

Gomide, T. L. F. (2008). Reflexos do planejamento de Manutenção Predial. Retrieved in 2018, April 4, from http://techne.pini.com.br/engenharia-civil/145/artigo286584-1.aspx

Gomide, T. L. F., Fagundes, J. C. P., No., Gullo, M. A., Vinagreiro, O., \& Flora, S. M. D. (2014). Inspeção de Manutenção Predial. Diretrizes Técnicas. São Paulo: Instituto de Engenharia.

Haniza Fakhrudin, I., Zailan Suleiman, M., \& Talib, R. (2011). The need to implement Malaysia's Building and Common Property Act 2007 (Act 663) in building maintenance management. Journal of Facilities Management, 9(3), 170-180. http://dx.doi.org/10.1108/14725961111148081.

Hauer, J., Bombach, V., Mohr, C., \& Masse, A. (2000). Preventive Maintenance for Local Government Buildings - a Best Practice Review. Minnesota: Office of the Legislative Auditor - Program Evaluation Division.

Instituto Brasileiro de Avaliações e Perícias de Engenharia de São Paulo - IBAPE. (2005). Norma de Inspeção Predial: check-up predial: guia da boa manutenção. São Paulo: IBAPE.

Kardec, A., \& Nascif, J. (2006). Manutenção: função estratégica. Rio de Janeiro: Qualitymark, 2006.

Khamidi, M. F., Olanrewaju, A. L. A., \& Idrus, A. (2010). Development of a Value Maintenance Management Model for Malaysian University Campuses. In Proceedings of the 18th CIB 
World Building Congress (pp. 150-157). Salford Quays, United kingdom: CIB Partner Organisations.

Kowaltovski, D. C. C. K., \& Deliberador, M. S. (2011). Caracterização do Processo de Projeto Escolar Público no Estado de São Paulo: potencialidades e desafios. Lagoa Nova: Universidade Federal do Rio Grande do Norte.

Kwon, S. H., Chun, C., \& Kwak, R. Y. (2011). Relationship between quality of building maintenance management services for indoor environmental quality and occupant satisfaction. Building and Environment, 46(11), 2179-2185. http://dx.doi.org/10.1016/j.buildenv.2011.04.028.

Lavy, S., \& Bilbo, D. L. (2009). Facilities maintenance management practices in large public schools, Texas. Facilities, 27(1/2), 5-20. http://dx.doi.org/10.1108/02632770910923054.

Lessa, A., \& Souza, H. L. (2010). Gestão da manutenção predial: uma aplicação prática (144 p.). Rio de Janeiro: Editora Qualitymark.

Lind, H., \& Muyingo, H. (2012). Building maintenance strategies: planning under uncertainty. Property Management, 30(1), 14-28. http://dx.doi.org/10.1108/02637471211198152.

Machado, M. C., Urbina, L. M. S, \& Eller, M. A. G. (2015). Manutenção Aeronáutica no Brasil: distribuição geográfica e técnica. Gestão \& Produção, 22(2), 243-253.

Moraes, L. O. G. (2012). Estudo da estrutura da informação no processo de gerenciamento da manutenção de edifícios de escritório (Monografia de Especialização). Universidade de São Paulo, São Paulo.

Morilha, A. M. (2011). Gerenciamento da manutenção predial: escolha e implantação de um sistema informatizado (Monografia de Especialização). Centro Universitário, Faculdade de Engenharia Industrial - FEI, São Paulo.

Nogueira, C. F. B., Saffaro, F. A., \& Guadanhim, S. J. (2018). Diretrizes de projeto para a redução de perdas na produção de Habitações de Interesse Social customizadas com painéis pré-fabricados em sistemas de construção a seco. Ambiente Construído, 18(1), 6789. http://dx.doi.org/10.1590/s1678-86212018000100210.

Odediran, S. J., Gbadegesin, J. T., \& Babalola, M. O. (2015). Facilities management practices in the Nigerian public universities. Journal of Facilities Management, 13(1), 5-26. http://dx.doi.org/10.1108/JFM-11-2013-0058.

Olanrewaju, A. L. (2012). Quantitative analysis of defects in University Buildings: user perspective. Built Environment Project and Asset Management, 2(2), 167-181. http://dx.doi.org/10.1108/20441241211280909.

Olanrewaju, A. L., Mohd, F. K., \& Arazi, I. (2010). Building maintenance management in a Malaysian University Campus: a case study. Construction Economics and Building, 10, 1/2, 1-14. http://dx.doi.org/10.5130/ajceb.v10i1/2.1593.

Olanrewaju, A. L., Mohd, F. K., \& Arazi, I. (2012). Appraisal of the building maintenance management practices of Malaysian universities. Journal of Building Appraisal, 6, 261-275.

Ornstein, S. W., \& Martins, C. A. (1997). Arquitetura, manutenção e segurança de ambientes escolares: um estudo aplicativo de APO. Revista Ambiente Construído, 1(1), 7-18.

Othuman, M. M. A. (2017a). Integrated design and approach of building maintenance management in the built environment. Robotica \& Management, 22(2), 51-56.

Othuman, M. M. A. (2017b). Significance of building maintenance management on life-span of buildings. Robotica \& Management, 22-1, 40-44.

Paes, R. F. S., \& Bastos, L. E. G. (2014). Qualidade ambiental na edificação: o caso das escolas públicas da cidade do Rio de Janeiro. Paranoá Cadernos de Arquitetura e Urbanismo, 12, 131-140.

Pinto, R. L., Gouvêa, M. A., \& Oliveira, B. (2014). Avaliação da qualidade do serviço terceirizado de manutenção em edificio commercial: o caso de uma organização pública. Gestão \& Produção, 21(2), 389-403. 
Pitt, M., Cannavina, D., Sulaiman, R., Mahyuddin, N., \& Wu, C. (2016). Hotel maintenance management in Sanya, China. Journal of Facilities Management, 14(4), 304-314. http://dx.doi.org/10.1108/JFM-12-2015-0034.

Pujadas, F. Z. A. (2007). Inspeção predial -ferramenta de avaliação da manutenção. In Anais do 14o Congresso Brasileiro de Engenharia de Avaliações e Perícias. Salvador, BA: IBAPE - Instituto Brasileiro de Avaliações e Perícias.

Shareghi, M., \& Faieza, A. A. (2011). Service oriented architecture and advancement of maintenance management information systems: a review. Scientific Research and Essays, 6(15), 3182-3188.

Silva, A. S. (2014). Plano de negócio: gestão da manutenção predial em redes bancárias de Curitiba (PR). (Monografia). Universidade Tecnológica Federal do Paraná, Curitiba.

Taralli, C. H. (2004). Demandas sociais e escola pública. In Anais do Seminário Internacional NUTAU - Demandas Sociais, Inovações Tecnológicas e a Cidade. São Paulo, SP: FAU/USP.

Vieira, A. C. V. (2003). Organização e gestão da manutenção das instalações e dos equipamentos fixos do DEEC/FCTUC (Dissertação de mestrado). Departamento de Engenharia Electrotécnica e de Computadores, Facudade de Ciências e Tecnologia, Universidade de Coimbra, Portugal.

Vieira, A. C. V. (2014). Organização e gestão da manutenção em estabelecimentos de ensino (Tese de doutorado). Departamento de Engenharia Electrotécnica e de Computadores, Faculdade de Ciências e Tecnologia, Coimbra, Portugal.

Vieira, A. C. V., \& Cardoso, A. J. M. (2005). Organização e gestão da manutenção de instituições de ensino In Anais do 80 Congresso Nacional de Manutenção. Lisbon, Portugal: APMI - Associação Portuguesa de Manutenção Industrial.

Vieira, A. C. V., \& Cardoso, A. J. M. (2010). Asset management of portuguese educational facilities. In J. E. Amadi-Echendu, K. Brown, R. Willet \& J. Mathew (Eds.), Definitions, concepts and scope of engineering asset management (EAMR - Engineering Asset Management Review, Vol. 1, part V, pp. 277- 295). USA: Springer.

Vieira, F. N. (2015). Proposta de elaboração de plano de manutenção para edificações a partir da obrigatoriedade legal da inspeção predial no contexto urbano das cidades (Dissertação de mestrado). Universidade Federal de Rio de Janeiro, Rio de Janeiro.

Worthing, D., Dann, N., \& Hills, S. (2003). Best practice in maintenance management for listed buildings. (Project Report). UK: Maintain Our Heritage.

Xenos, H. G. (2004). Gerenciando a manutenção produtiva: o caminho para eliminar falhas nos equipamentos e aumentar a produtividade. Nova Lima: INDG.

Yik, F. W. H., Lai, J. H. K., Chau, C. K., Lee, W. L., \& Chan, K. T. (2010). Operation and maintenance: the perception of Hong Kong's general public about building services. Journal of Facilities Management, 8(2), 130-142. http://dx.doi.org/10.1108/14725961011041170. 